\title{
Role of Hedging Mechanism in Maintaining Volatility Cash Flow and Growth Opportunity and Their Impact on Investor Reaction
}

\author{
Hartono $^{1}$ \\ Oktavianus Pasoloran ${ }^{2}$ \\ Fransiskus E. Daromes ${ }^{3}$ \\ ${ }^{1,2,3}$ Faculty of Economics and Business, University of Atma Jaya Makassar, Indonesia \\ email: hartono.mkz@gmail.com
}

DOI: https://doi.org/10.24843/JIAB.2020.v15.i01.p03

\begin{tabular}{l}
$\begin{array}{l}\text { Jurnal Ilmiah Akuntansi } \\
\text { dan Bisnis } \\
\text { (JIAB) }\end{array}$ \\
\hline Volume 15 \\
Issue 1 \\
January 2020 \\
Page 23 - 34 \\
p-ISSN 2302-514X \\
e-ISSN 2303-1018 \\
\hline ARTICLE INFORMATION: \\
\hline Received: \\
29 July 2019 \\
Revised: \\
22 November 2019 \\
Accepted: \\
06 January 2020 \\
\hline
\end{tabular}

\begin{abstract}
This study aims to investigate the role of forward contract hedging in maintaining volatility cash flow and growth opportunity and its impact on investor reaction. The population in this study included 242 non-financial companies listed on the Indonesia Stock Exchange from 2013-2017. The sample was determined using purposive sampling, and path analysis was employed to analyze the data. Results show that forward contract hedging mediates the effects of volatility cash flow and growth opportunity on investor reaction. This research is expected to provide insights so that company management can improve performance properly and increase investor confidence through the application of hedging, thereby maintaining volatility cash flow and growth opportunity. Keywords: Cash flow volatility, growth opportunity, hedging forward contract, investor reaction.
\end{abstract}

\section{INTRODUCTION}

International business is a business activity performed by companies across countries. International business is encouraging more multinational companies to emerge. This led to increasing transactions between companies through imports and exports. Increased import and export transactions constrain companies to finalize existing transactions with foreign exchange.

Transactions that occur in foreign currencies can inflict a significant impact on the presentation of financial statements because they can cause foreign exchange differences. Uncertain exchange rate fluctuations can occur due to monetary economic turmoil such as inflation rates, changes in fiscal and monetary policy, interest rates and economic growth that different (Nugraha, 2017).

The company that had dominated the largest pay-tv market share, MNC Sky Vision from 20102012, recorded profits in a row. However, in 2013 the company experienced a decline in net income, even in the Annual General Meeting decided not to distribute dividends due to the company's negative profit balances. MNC Sky Vision suffered the highest loss when in 2015, up to 776 billion Rupiah, 400 percent from the previous year's loss of 155 billion Rupiah due to fluctuations in Rupiah against United States Dollar. The company did not hedge with a composition of 80 percent of long-term debt denominated in United States Dollars or equivalent to 780 billion Rupiah (Hanifan, 2017). These losses triggered investors to react as indicated by the company's share price of MNC Sky Vision which declined when the company announced the loss to the public.

MNC Sky Vision that suffered loss would have to take appropriate action to avoid the risk of loss from fluctuations in currency exchange rates that would be brought the company into a state of financial difficulties. The company can manage that risk in several ways, one of which can be done through hedging activities.

In 2013, besides MNC Sky Vision, PT Perusahaan Listrik Negara (PLN) also experienced a decrease in net profit for 68.7 percent from the previous year. PLN's Managing Director, Nur 
Pamudji said that the decline in PLN's net profit due to an increase in foreign exchange loss as big as $\mathrm{Rp}$ 4.1 trillion from Rp 1.8 trillion in 2011 to Rp 5.9 trillion in 2012 (Purwanto, 2013). These consequences happen because of the translation of liabilities in foreign currencies. At that time the Rupiah was experiencing a weakened of the United States Dollar. The decline in net profit was mainly due to non-cash transactions.

Forward contracts are often used by companies as a form of hedging because of their simple characteristics when compared to other derivatives. Hull (2018:849) stated that forward contracts were an agreements to buy or sell assets at a certain time in the future at a certain price. This ease allows companies to obtain foreign exchange at a predetermined price, quantity and date, even companies can obtain foreign exchange every day for several days before the contract period (Nugraha, 2017).

According to Ehrhardt \& Brigham (2011:889902), risk management carried out by companies could maintain the volatility of cash flow. Where one form of risk management that can be done through hedging policies. Cash flow is important for the company because cash flow can be an indicator of companies that experience a condition of financial difficulties characterized by a decrease in the company's cash flow than expected. The company's cash flow could describe the company's operational activities in managing assets owned to generate value-added for the company.

The companies' expectancy also can be predicted through other indicators, such as the company's growth opportunity. The opportunity from the company to grow can be observed from the level of sales growth and company assets growth that represents the increase or decrease in the company's ability over time. Companies that able to consistently maintain the level of sales growth and assets shown that the company's management succeeds in managing the company.

Companies that predicted to have fast growth in the future can use shares and debts to maintain the company's operations. So, the companies have to assured investors and creditors that the company has good financial stability to cover its obligations and generate returns for investors that can be shown as a good company's growth opportunities.

Ameer (2010), Chaudhry, Mehmood, \& Mehmood (2014) examined the determinants of hedging practices carried out by companies. The results of his research show that the volatility of cash flow and the opportunity for company growth have a positive effect on the hedging decisions of the company. This shows that cash flow volatility can affect the hedging decisions of the company.

Koonce, Miller, \& Winchel (2015) examined the investor's reaction in the use of derivatives as a way for companies to manage business risk by taking into account industrial factors. The study was an experimental study conducted on a number of selected participants. The results of his research on the use of derivatives to manage business risk are seen to be profitable by investors, especially if done by companies in industries that do not use derivatives on average.

The research to test investor ratings for companies is considered to perform safe better than risk companies after obtaining low grudge from investors conducted by Iyer \& Harper (2017).. Income statement data from his research were obtained from Compustat, which is quarterly from 1980 to 2014. The results of his research indicated that companies with high cash flow volatility are more likely to be both shocking and disappointing in connection with operating performance which results in investors reacting negatively to the company. In addition, this study also found a negative relationship between investor grudge and return on risk companies.

Nugraha (2017) examined the role of cash flow volatility and growth opportunities in suppressing financial distress by increasing the use of hedging forward contracts in non-financial companies in Indonesia in the 2014-2016 period. The results of his research indicated that the volatility of cash flow and the opportunity for growth of the company has a significant influence on hedging forward contracts through mediating financial distress variables.

Difficulties to predict business environments such as a trade war, changes in interest rates make companies need to do risk management to avoid the risk of exchange rate changes. Even though the exchange rate looks stable, the company still needs to do hedging, because no one can guarantee that the exchange rate won't change. The difference between this research and previous research is the variable investor reaction which describes the investor's reaction to the risk management carried out by the company, in this case, hedging policy. Thus, the company's risk management policy through hedging policies is expected to be good news for investors that the company has good financial stability, which is shown from the volatility of cash flow and growth opportunities for the company's growth. 
The importance of this research resides in the hedging policy conducted by the companies as a company's risk management strategies. Cash flow volatility and growth opportunity become a signal to investors regarding the company's feasibility to obtain investment. So, companies need to maintain volatility in cash flow and growth opportunities through hedging policies. This can trigger investor reaction because the company is considered to have carried out risk management well.

Management in taking risk management decisions related to exchange rate fluctuations using hedging can be explained by signal theory. The signaling theory originated from Akerlof's writings in 1970 that explains the asymmetry of information. The phenomenon observed by Akerlof at that time was the sale of used cars. Where Akerlof (1970), examines the differences in the information held by the seller and buyer of used cars related to product quality.

The concept put forward by Akerlof in 1970 was then developed by Spence three years later who wrote about the basic equilibrium signaling model. Spence (1973) stated that the owner of the information given a signal in the form of information where they tried to provide relevant information so that it can be utilized by the recipient of the information. Signaling is an impact caused by the information asymmetry. The concept of information asymmetry states that in some economic transactions, inequality in access to information is a common occurrence for sales and purchase transactions.

Scott (2015:23), adverse selection defined information asymmetry in which one or more parties in a business transaction, or potential transaction, had an information advantage over another party. Akerlof (1970), to overcome the problem of adverse selection, sellers needed to communicate their products to buyers by giving signals in the form of information related to the quality of products sold.

Larcker \& Tayan (2011:190), risk management is a process in which companies evaluate and reduce exposure to risk. Vaughan and Vaughan (2014:637) defined risk management as a scientific approach to managing risk by anticipating possible losses, designing, and implementing procedures that minimize the occurrence of losses or the financial impact of losses that occur. The company's risk management can be in the form of actions, policies, and procedures implemented by management to reduce the likelihood of adverse outcomes and to increase the likelihood and benefits of positive or beneficial results.
Volatility can be defined as fluctuations in the return of a security or portfolio in a certain period (Tumirin, 2005). Volatility can also be interpreted as a change in cash flow that can go up or down in a short time. Volatility in cash flows can make it difficult for companies to predict the availability of cash in the future.

A company's growth opportunity can be an indicator of a company's growth. Evans (1987) defined a company's growth opportunity as the company's ability to maintain or improve its economic position. Companies that would have to develop need chances and opportunities. Then the chances for the company to grow is very important for the company to fulfill. The company's growth can be seen from its growth ratio which illustrates the company's ability to maintain its economic position amid an uncertain business environment.

Hedging techniques can be grouped into futures, forwards, swaps and options. Brigham \& Houston (2017:608) stated that forward contracts are agreements where one party agrees to buy a commodity at a certain price on a certain date in the future and the other party agrees to sell the product. While futures contracts are similar to forward contracts, the difference lies in futures contracts, which are traded on the stock exchange to buy or sell assets in the future at a predetermined price. Swap contracts are an exchange of cash payment obligations (Marcus, Brealey, \& Myers, 2008:684). An option contract is a contract that gives the holder the right to buy / sell assets at a price and a predetermined time period (Aslikan \& Rokhmi, 2017).

Investor's reaction is shown through the significant changes in the company's stock price at the time of the earnings announcement or the publication of financial statements containing relevant information. The significant change is that there is a significant difference between the actual return and the expected return. Where the return that has occurred is referred to actual return, while the expected return which is the expected return of the investor to be obtained in the future where it has not occurred. Then an announcement of earnings or financial statements that contain relevant information will be able to trigger investor reactions so that abnormal returns can occur.

Research about the effect of cash flow volatility on the decision to use hedging was conducted by Ameer (2010), Naveed et al. (2014) and Goklas (2016), concluded that there is a positive and significant relationship between the variable volatility 
of cash flow (cash flow volatility) to the hedging policy of the company. Whereas research conducted by Klimczack (2008) and Nugraha (2017), shows that cash flow volatility variable has a negative influence on company hedging policies.

Cash flow volatility can indicate high uncertainty in the form of the company's cash availability in the future. Hedging is done as a form of risk management to minimize the risk of exchange rate changes that can disrupt the volatility of the company's cash flow. So, companies with high cash flow volatility will certainly be encouraged to increase hedging activities so that the company's cash availability in the future becomes more secure. Then the hypothesis formulated in this study is as follows:

$\mathrm{H}_{1}$ : Cash flow volatility has a significant effect on hedging forward contracts.

Research related to company growth opportunities and hedging was conducted by Ameer (2010), Repie \& Sedana (2015), Dewi \& Purnawati (2016), and Nugraha (2017), in his research found a significant positive relationship between growth opportunity and company hedging policies. Conflicting results were found in the study of Goklas (2016), which revealed that growth opportunity was negatively related insignificantly to company hedging policies.

Companies with high growth opportunities will require large funds to do business development. When a company develops a business, the risk faced by the company becomes even greater, for example, related to the company's ability to pay off its obligations. So, companies need proper risk management to minimize the risks faced by the company. One form of risk management is hedging. Then the higher the opportunity for a company to grow needs to be balanced with hedging activities as a form of risk management. Then the hypothesis formulated in this study is as follows:

$\mathrm{H}_{2}$ : Growth opportunity has a significant effect on hedging forward contracts

Research conducted related to cash flow volatility and investor reaction was conducted by Iyer and Harper (2017), who found that high cash flow volatility was more likely to be surprising which resulted in investors acting negatively, this is in line with Altuntas et al. (2017), who found that cash flow volatility had a negative effect on firm value. However, this research contradicts Chi \& Su (2017), who found that cash flow volatility has a positive relationship with firm value, especially in large, longstanding companies.

Companies that have an increased cash flow from another period are the investor's expected. However, company's volatility also shows uncertainty about the availability of cash flow, so the company needs to do cash management so that the company's cash flow becomes more predictable. An increase in the company's cash flow is expected by investors so that the company can have enough cash to invest so that it can generate returns for investors. Then the hypothesis formulated in this study is as follows: $\mathrm{H}_{3}$ : Cash flow volatility has a significant effect on investor reaction.

Research conducted related to company growth opportunities and investor reactions conducted by Che et al. (2017) who found companies with high growth opportunities obtained positive reactions from investors. This is supported by Hermuningsih (2013) and Andawasatya et al. (2017), who found that the company's growth opportunity positively and significantly affected the value of the company. However different results were found by Paminto et al. (2016), which stated that company growth had a negative and significant effect on firm value.

The company's growth opportunity is a sign that the company has favorable prospects. Investors expect companies with high growth opportunities to generate high profits so they can make a profit. So, companies with high growth opportunities will get a better response from investors when compared to companies that have low growth opportunities. Then the hypothesis formulated in this study is as follows: $\mathrm{H}_{4}$ : Growth opportunity has a significant effect on investor reaction

Research conducted related to hedging and investor reaction was conducted by Koonce et al. (2015) who found the use of derivatives to manage business risk is seen as profitable by investors. This is supported by Nova et al. (2015), who found hedging with swap and forward contracts can increase company value. However, research conducted by Costa and Singh (2013), which states that hedging by companies has a negative but not significant effect on the company's value. In addition, Nguyen (2015), found risk management in the form of hedges can increase company value but not statistically significant.

Risk management is a form of company policy to anticipate the risks faced by the company. Either 
of risk management is hedging. Hedging done by companies indicates that the company's management is trying to reduce the risks that the company must face. Hedging is a positive signal that can trigger investors to respond positively to the information received. Then the hypothesis formulated in this study is as follows:

$\mathrm{H}_{5}$ : Hedging forward contract has a significant effect on investor reaction

Research on cash flow volatility, hedging, and investor reaction was conducted by Iyer and Harper (2017), who found that high cash flow volatility was more likely to be surprising which resulted in investors reacting negatively. Also, research related to cash flow volatility and hedging by Ameer (2010) and Goklas (2016) concluded that there was a significant positive relationship between cash flow volatility and hedging policies. While research conducted by Klimczack (2008) and Nugraha (2017), shows that the variable cash flow volatility has a negative influence on hedging policy.

Investors like a company with good financial stability. High cash flow volatility of the company makes the company faced with the risk of cash availability in the future. So, companies need to provide guarantees to investors of their financial stability which is demonstrated through risk management. Risk management can be done through hedging policies to guarantee the availability of cash to investors. Then the hypothesis formulated in this study is as follows:
$\mathrm{H}_{6}$ : Hedging forward contracts mediate the effect of cash flow volatility on the investor reaction

Research on the company's growth opportunities, hedging, and investor reaction was conducted by Che et al. (2017) who found companies with high growth opportunities obtained positive reactions from investors. Also, research studies related to company growth opportunities and company hedging were conducted by Ameer (2010), Repie \& Sedana (2015), Dewi \& Purnawati (2016), and Nugraha (2017), in their research found a significant positive relationship between growth opportunity and company hedging policy. Conflicting results were found in the study of Goklas (2016), which revealed that growth opportunity was negatively related insignificantly to company hedging policies.

Companies with good growth opportunities will be faced with a higher risk when the company will expand. This makes the management of companies need to do risk management one of them by doing hedging. Companies that do hedging try to minimize the risks that may be experienced by the company so that it can have an impact on the company's growth opportunities that are maintained at the planned level. Then the hypothesis formulated in this study is as follows:

$\mathrm{H}_{7}$ : Hedging forward contract mediates the effect of growth opportunity on investor reaction.

Following with the explanation of the hypothesis, the theoretical framework of this study can be described as follows

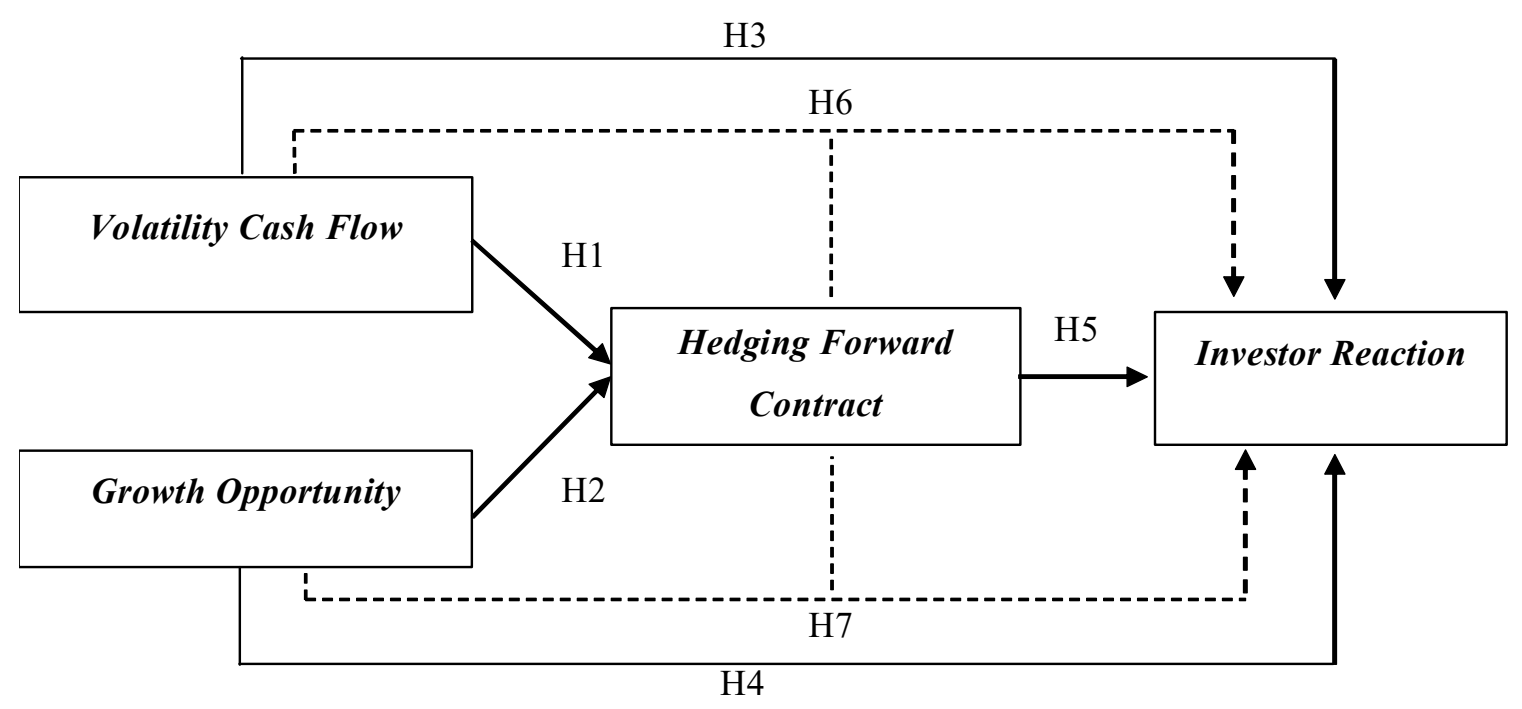

Source: Processed Data (2019)

Figure 1. Theoretical Framework 


\section{RESEARCH METHOD}

The population in this study are non-financial companies listed on the Indonesia Stock Exchange (IDX) for the period 2013-2017. This research does not include financial companies because some financial companies are the facilitator of hedging services that can bias the research results related to the role of hedging. The research period was chosen in 2013-2017 because there were large exchange rate fluctuations in that period. The sampling method in this study uses purposive sampling with sample criteria that is to publish a complete annual report in Rupiah from 2013-2017. The source of data in this study is secondary data in the form of annual reports in the period 2013-2017 obtained from www.idx.co.id. The independent variable of this study is the cash flow volatility and growth opportunity. The dependent variable in this study is the investor reaction. The mediating variable in this study is hedging forward contracts.

The data collection method used is documentary observation. Documentary observation is done by obtaining information through observing written documents related to research. In this study, these documents are the company's financial statements and annual reports. Besides, researchers also sought stock price data through the website www.dunia invest.com.

The reaction of investors in this study was measured using abnormal returns. Abnormal return is the difference between the actual return and the expected return. Measurement using Cumulative Abnormal Return (CAR) is considered more accurate because it considers the addition of beta as a consideration of the risk in calculating stock returns. CAR is the amount of abnormal adjusted return (AR) obtained using the following regression formula (Combs and Skill, 2003):

Then, the adjusted abnormal profit of a company is calculated using the following formula:

$R_{i t}=\alpha_{i}+\beta_{i} R_{m t}+\varepsilon_{i t}$

Where:

$\mathrm{R}_{\mathrm{it}}=$ return on securities $\mathrm{i}$ at time $\mathrm{t}$

$\mathrm{R}_{\mathrm{mt}}=$ market return on the designated market

$\beta=$ beta of stock $\mathrm{i}$

$\alpha=$ constant

$\varepsilon \quad=$ estimation error

Then, the adjusted abnormal return of a company is calculated using the following formula:

$$
A R_{i t}=R_{i t}-\left(\alpha_{i}+b_{i} R_{m t}\right)
$$

Where:

$\mathrm{a}$ and $\mathrm{b}=$ least squares parameter estimates obtained from regression $\mathrm{R}_{\mathrm{it}}$ on $\mathrm{R}_{\mathrm{mt}}$ during the estimation period

CAR is the cumulative AR in accordance with those chosen.

According to Helfert (2001) hedging is a strategy to offset investment risk by using a contract where the potential gains and losses will eliminate each other. Hedging forward contract in this study uses the formulation proposed by (Moguillansky, 2003):

$$
\text { Hedging forward contract }(\mathrm{F})=\left(\left(S \frac{1+i f}{1+i d}\right) \times \mathrm{NFC}\right)
$$

where:

$$
\begin{array}{ll}
\mathrm{S} & =\text { Spot Rate } \\
\text { if } & =\text { Domestic interest rates } \\
\text { id } & =\text { Foreign interest rates (United States) } \\
\text { NFC } & =\text { Net Foreign Currency }
\end{array}
$$

Cash flow volatility is a change from cash flow that can go up or down in a short time. Cash flow volatility is the standard deviation of the cash flow or distribution index of the company's cash flow distribution (Dechow and Dichev, 2002). Volatility Cash Flow used in this study was measured by the formulation:

$$
\text { Volatility Cash Flow }=\sigma \frac{\text { Cash Flow of Operations }}{\text { Total Assets }}
$$

Evans (1987) defines a company's growth opportunity as the company's ability to maintain or improve its economic position. Growth opportunity in this study uses a comparative measurement between MVE (market value of equity) and BVE (book value of equity). Mathematically can be formulated as follows:

Growth Opportunity $=\frac{M V E}{B V E}$

where:

MVE = Number of shares outstanding $\times$ Closing Price

BVE $=$ Total Asset - Total Liabilities

The data analysis method used in this study is path analysis. Path analysis is an extension of the 
multiple linear regression analysis used to estimate the causal relationships between variables that have been predetermined based on theory. This method has advantages compared to linear regression because in addition to finding direct effects, path analysis can also find indirect effects in the relationship between variables through mediating variables. So that the path analysis is suitable for use in this research model because it can determine the indirect effect in the relationship between variables through mediating variables. This study uses Statistical Package for the Social Science (SPSS) software to manage data statistically.

\section{RESULTS AND DISCUSSION}

The objects of this research are all non-financial companies listed on the Indonesia Stock Exchange (IDX) for the period 2013-2017 as outlined in the form of annual reports. The independent variable in this study is the volatility of cash flow and growth opportunity with the hedging forward contract and investor reaction dependent variables. The sample selection in this study uses a purposive sampling method. The number of companies that met the sample criteria for each year was 242 companies from 564 companies listed on the IDX. Because the period in this study is 5 years, from 2013-2017, the total number of units of analysis is 1,210 units.

Table 1. Sample Selection Summary

\begin{tabular}{lc}
\hline \multicolumn{1}{c}{ Sample Selection } & Sample (N) \\
\hline Number of companies registered continuously on the IDX during & 564 \\
$2013-2017$ & \\
Number of financial companies & $(93)$ \\
Number of companies with incomplete financial data & $(229)$ \\
Total companies used as research samples & 242 \\
\hline
\end{tabular}

Source: Processed Data (2019)

Data processing is performed using SPSS software with a total of 1,210 data, there are 377 indications of data that are outliers because the z-score obtained outside the vulnerable $\pm 2,58$ which makes the data excluded from the analysis. Then the total sample used in this study was 833 units of analysis.
Data normality test aims to see the distribution of data used in the analysis. Data is normally distributed if the Kolmogorov-Smirnov test results have a probability level of significance greater than 0.05 (Ghozali, 2012:160). Following are the results of the normality test presented in Table 2.

Table 2. Normality Test Results

\begin{tabular}{cccc}
\hline Equation & $\begin{array}{c}\text { Kolmogorov- } \\
\text { Smirnov Z }\end{array}$ & Sig. & Result \\
\hline Substructure 1 & 1.022 & 0.247 & Normal distribution \\
Substructure 2 & 0.915 & 0.373 & Normal distribution \\
\hline
\end{tabular}

Source: Processed Data (2019)

$\mathrm{F}$ test (F-test) is used to determine whether the independent variables together (simultaneously) significantly influence the dependent variable. In other words, to find out whether the regression model can be used to predict the dependent variable or not.

Table 3. Statistical Test Results F (F-test)

\begin{tabular}{|c|c|c|c|}
\hline Endogenous Variable & Exogenous Variables & $\mathrm{F}$ & Sig. \\
\hline Hedging Forward Contract & $\begin{array}{l}\text { Volatility Cash Flow } \\
\text { Growth Opportunity } \\
\text { Volatility Cash Flow }\end{array}$ & 8.971 & 0.000 \\
\hline Investor Reaction & $\begin{array}{l}\text { Growth Opportunity } \\
\text { Hedging Forward Contract }\end{array}$ & 4.735 & 0.003 \\
\hline
\end{tabular}

Source: Processed Data (2019)

Based on the ANOVA or F-test results shown in Table 3. It shows that for equation 1 substructure that tests the effect of volatility cash flow and growth opportunity on hedging forward contracts has a significance value of $0.000<0.05$. This shows that there is an influence between volatility cash flow and growth opportunity together or simultaneously on hedging forward contracts.

Substructure 2 equation that examines the effect of volatility cash flow, growth opportunity and hedging forward contracts to the investor reaction has a significance value of $0.003<0.05$. This shows that 
there is an influence between volatility cash flow, growth opportunity and hedging forward contract on investor reaction.

Hypothesis testing is done by using a regression model in path analysis to predict the relationship between exogenous variables and endogenous variables. Based on the results of data processing that has been done, the path diagram model can be described as follows:

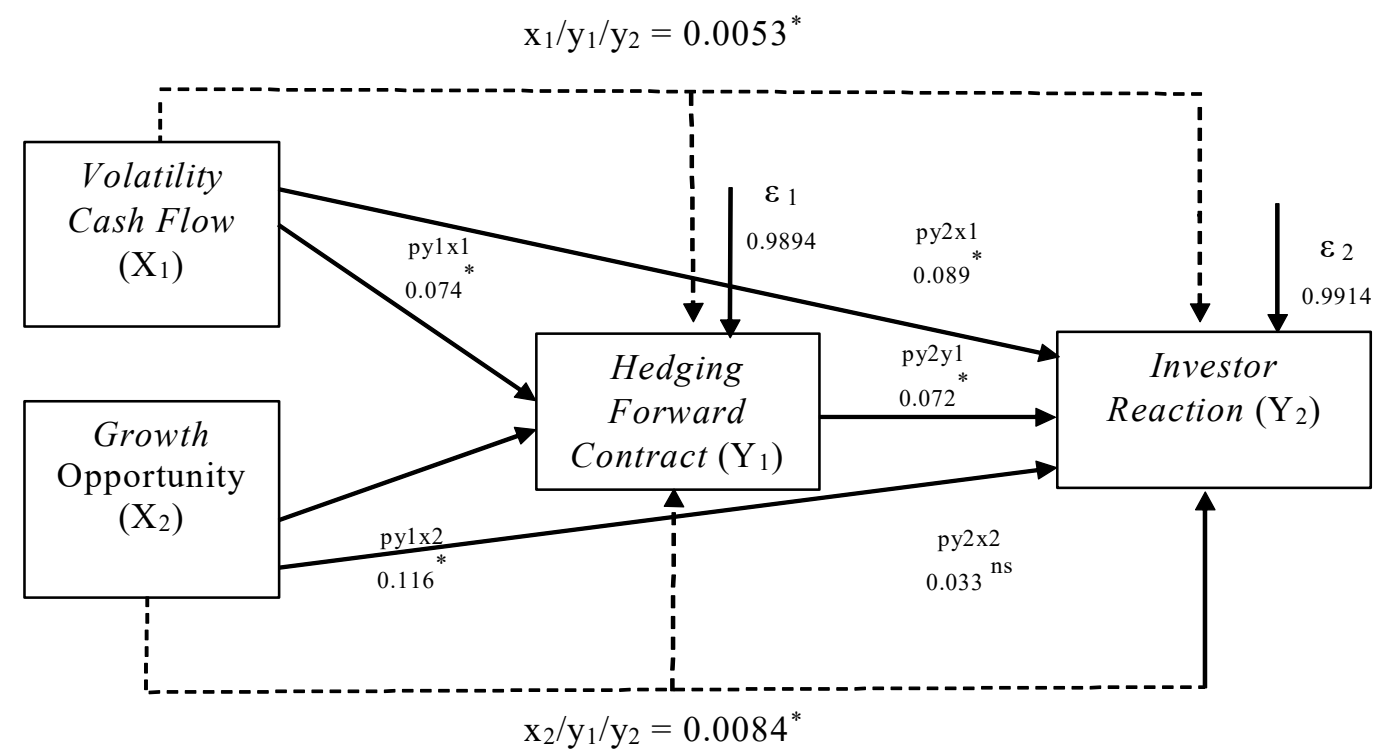

Figure 2. Results of Path Analysis Model

Source: Processed Data (2019)

Table 3. Path Analysis Result

\begin{tabular}{lccc}
\hline \multicolumn{1}{c}{ Model Structure } & Coefficient & Sig. & Result \\
\hline $\begin{array}{l}\text { Substructure 1 } \\
\text { (The effect of cash flow volatility and growth }\end{array}$ & & & \\
opportunity on hedging forward contracts) & & & \\
$\begin{array}{l}\text { Volatility Cash Flow } \\
\text { Growth Opportunity }\end{array}$ & 0.074 & 0.034 & Significant \\
$\begin{array}{l}\text { Substructure 2 } \\
\text { (The effects of volatility cash flow. growth }\end{array}$ & & 0.001 & Significant \\
opportunity and hedging forward contracts on & & & \\
investor reaction) & 0.089 & 0.010 & \\
Volatility Cash Flow & 0.033 & 0.351 & Significant \\
Growth Opportunity & 0.072 & 0.038 & Significant \\
Hedging Forward Contract & & & \\
\hline Source: Processed
\end{tabular}

Source: Processed Data (2019)

Testing the indirect effect in this study using the Sobel Test (Ng \& Daromes, 2016). Research variables are said to have an indirect effect on each

other if all tested path coefficients are significant ( $p$ $<0,05$ ).

Table 4. Indirect Test Results (Sobel Test)

\begin{tabular}{cccccc}
\hline $\begin{array}{c}\text { Independent } \\
\text { Variable }\end{array}$ & $\begin{array}{c}\text { Intervening } \\
\text { Variable }\end{array}$ & $\begin{array}{c}\text { Dependent } \\
\text { Variable }\end{array}$ & $\mathrm{t}$ & sig & Result \\
\hline $\begin{array}{c}\text { Volatility Cash } \\
\text { Flow }\end{array}$ & $\begin{array}{l}\text { Hedging } \\
\text { Forward } \\
\text { Contract }\end{array}$ & $\begin{array}{c}\text { Investor } \\
\text { Reaction }\end{array}$ & 2.127 & 0.033 & Significant \\
$\begin{array}{c}\text { Growth } \\
\text { Opportunity }\end{array}$ & $\begin{array}{c}\text { Forward } \\
\text { Contract }\end{array}$ & $\begin{array}{c}\text { Investor } \\
\text { Reaction }\end{array}$ & 3.333 & 0.001 & Significant \\
\hline
\end{tabular}

Source: Processed Data (2019) 
The test results of the influence of variable cash flow volatility on hedging forward contracts show a regression coefficient of 0.074 and a significance probability value of 0.034 , so it can be concluded statistically that volatility cash flow has a positive and significant effect on hedging forward contracts. Then the first hypothesis in this study was accepted.

The positive influence in this study indicates that the more fluctuating company cash flows will increase the application of hedging policies. This can occur because the company wants to experience increased cash flow from each period and has sufficient cash when there are obligations that are due, so management needs to take hedging policies as a risk management strategy and to show investors and creditors that the company is in a state that is stable financial management. The results of this study are consistent and in line with research conducted by Ameer (2014), Chaudhry et al. (2014), Goklas \& Wahyudi (2016) who concluded that volatility cash flow has a positive and significant relationship to hedging decisions. In addition, this study is not in line yet consistent with research conducted by (Klimczak, 2008) and Nugraha (2017).

The test results of the influence of the growth opportunity variable on hedging forward contracts show a regression coefficient of 0.116 and a significance probability value of 0.001 , so it can be concluded statistically that the company's growth opportunity has a positive and significant effect on hedging forward contracts. This shows that growth opportunity affects the company's decision to hedge a forward contract. Then the second hypothesis in this study was accepted.

Growth opportunity from companies is a good signal for investors. But increasing opportunities for growth can also make companies have to bear even greater risks. Company management needs to convince investors of their ability to manage risk so that company goals can be achieved. Then the company management also needs to disclose the risk management policies undertaken, one of which is the company hedging policy. So the company's policy to conduct hedging provides information that the company is in a stable condition by conducting financial management and good risk management which is a positive signal for investors. The results of this study are in line and consistent with research conducted by Ameer (2010), Repie \& Sedana (2015), Dewi \& Purnawati (2016), and Nugraha (2017), which concludes the opportunity for company growth to have a positive relationship with hedging decisions.
But it is not in line and not consistent with research conducted by Goklas \& Wahyudi (2016).

The results of the test of the influence of the variable volatility cash flow on the reaction investor showed a regression coefficient of 0.089 and a significance probability value of 0.010 , so it can be concluded that volatility cash flow has a positive and significant effect on the investor reaction. This shows that the higher volatility cash flow will increase investor reaction. Then the third hypothesis in this study was accepted.

Information signals that describe the condition of the company in a stable state are shown by the company through an increase in operating cash flow from one period to another. When a company gets an increase in its operating cash flow obtained from paying off receivables, this makes the company have more free cash flow to use, either to invest or be used to pay off the company's obligations that are due. The availability of company cash when needed shows that the company is financially stable, and can utilize the free cash flow that is owned by the company to develop its business. Information about the company's cash availability is a positive signal that can make investors react positively because of the guaranteed financial stability of the company. The results of this study are in line and consistent with research conducted by Chi \& Su (2017), who found that high cash flow volatility will improve investors' valuation of the company. But the results of this study are not in line and are not consistent with research conducted by Iyer \& Harper (2017) and Altuntas, Liebenberg, Watson, \& Yildiz (2017).

The test results of the influence of growth opportunity variables on investor reaction show a regression coefficient of 0.033 and a significance probability value of 0.351 , so it can be concluded statistically that growth opportunity has no significant effect on investor reaction. This shows that the higher growth opportunity will increase investor reaction, but the effect is not strong. Then the first hypothesis in this study was rejected.

The test results obtained are positive but not significant, this shows that there are investors who are still considering growth opportunities that describe the company's future prospects in determining investment decisions. Although not significant, a high growth opportunity can make a company more potential to develop in the future so that it can generate returns for investors.

High growth opportunity will be able to increase investor reaction because companies with high 
growth opportunity will have more potential to develop in the future. Companies with high growth opportunities will experience an increase in the number of assets in this case the company's current assets obtained from the company's operating activities as a result of increased sales. When the company experiences an increase in sales, the profit earned by the company will also increase. This profit will guarantee the continuity of the company and can guarantee investors to get a return. Then the investor will give an assessment in accordance with the prospects owned by the company that is reflected through the company's market value.

A company's high growth opportunity will make investors react positively, conversely companies with low growth opportunities will make investors react negatively. The results of this study are consistent but not in line with research conducted by Che, Liebenberg, Liebenberg, and Morris (2018) which states that companies with high growth opportunities get a positive reaction from investors and are not in line with and inconsistent with research conducted by Paminto, Setyadi, and Sinaga (2016) which states that company growth has a negative effect on firm value.

The test results of the influence of hedging forward contract variables on investor reaction show a regression coefficient of 0.072 and a significance probability value of 0.038 , so it can be concluded statistically that hedging forward contracts have a positive and significant effect on investor reaction. This shows that the hedging forward contract policy influences investors' decisions in making investment decisions. Then the fifth hypothesis in this study was accepted.

Investors consider hedging as a form of strategy to manage risk, so the company can generate returns for investors. Hedging has been considered as a requirement that must be met by the company in order to provide a sense of security for investors in investing in the company. The hedging strategy undertaken by the company aims to maintain cash flow primarily from the company's operating activities, so that the company can obtain an increase in cash from increased sales and ensure the availability of company cash when there is a debt that is due. The results of this study are in line and consistent with research conducted by Koonce et al. (2015) who found the use of derivatives to manage business risk is seen as profitable by investors. But it is not in line and not consistent with research conducted by Costa \& Singh (2013).

The results of testing the mediating role of hedging forward contracts to the effect of variable volatility cash flow on investor reaction based on the results of the sobel test in table 4 shows that the $p$ value of the sobel test is 0.0334 with a sobel statistical value of 2.127. This shows the hedging forward contract mediates the relationship of volatility cash flow to the investor reaction. Then the sixth hypothesis in this study was accepted.

Management wants to convey information to investors that the company is in a stable condition. The company's stability can be achieved through risk management planning in the form of hedging policies conducted by the company to ensure the volatility of the company's operating cash flow can increase for each period. The risk management undertaken enables the company to guarantee the availability of its cash flow in the future. The company can guarantee the availability of cash in the future through the role of risk management. Operating cash flow that has increased can occur due to increased sales, which will affect the company's assets in the form of an increase in trade receivables or company cash, but the company's reduced inventory due to increased sales makes the company needs to buy inventory that will have an impact on increasing debt.

The results of testing the mediating role of hedging forward contracts on the effect of the growth opportunity variable on investor reaction based on the results of the sobel test in Table 4. shows that, the $p$ value of the sobel test is 0.001 with the sobel statistical value of 3.333. This shows that the hedging forward contract mediates the relationship between growth opportunity and investor reaction. Then the seventh hypothesis in this study was accepted.

Investors not only pay attention to the prospects of the company in the future, but also consider the risks of their investment if the company experiences losses. High growth opportunities for companies are also faced with a number of risks, for example the company's ability to pay off obligations when due. So the risk management in the form of hedging needs to be done by to minimize the risks borne by the company. A high level of growth opportunity can be characterized by an increase in assets in the form of excess free cash flow to be used by companies to invest. So companies that have excess cash to invest will attract investors' attention because the company is considered to have financial stability so that it can make investments.

\section{CONCLUSION}

Based on testing and data analysis that has been done, it can be concluded that volatility cash flow 
has a significant positive effect on investor reaction through hedging forward contracts as an intermediary variable. The results of this study indicate that the higher the volatility of cash flow of a company shows that the company is difficult to guarantee the availability of cash, the company needs to do good risk management through hedging policies, so that the company's operating cash flow can continue to increase, and can provide a guarantee of cash availability when the company must pay off obligations. This gives confidence to investors that the company is eligible for investment because the company is stable in its financial management.

Growth opportunity has a significant positive effect on investor reaction through hedging forward contracts as an intermediary variable. The results of this study indicate that when companies have the opportunity to grow well, the company will also be faced with an increasingly greater risk, then company management needs to manage risk one of them through hedging policies. Risk management in addition to minimizing the risks faced by the company is also expected to increase the company's current assets so as to enable the company to guarantee its obligations then the excess is used for investment in order to maximize returns for investors. This gives investors confidence that the company, in addition to having good prospects, also has good financial stability through risk management.

For investors, this research is expected to provide practical implications in the form of an overview of the company's financial condition and prospects of the company, as well as hedging policies implemented by the company that can be used as consideration in investment decision making. For companies, this research is expected to make management consider more the use of hedging for the company, because management is sometimes still hesitant to use hedging because of the costs incurred to do hedging. In addition, this research is expected to be able to contribute and reference future research regarding risk management, especially hedging.

The limitation of this study is the cash flow volatility referred to in this study only refers to the operating cash flow of the company which does not consider investment and funding cash flows. Suggestions for further research can consider other measuring tools of the variable volatility cash flow, so it is not limited to cash flow from operating activities. Future studies are also expected to consider the company's value variable as the dependent variable to see the long-term effects of using hedging forward contracts. Future research can also add financial distress as an independent variable to see the role of hedging in preventing companies from experiencing financial distress.

\section{REFERENCES}

Akerlof, G. A. (1970). The Market for "Lemons": Quality Uncertainty and the Market Mechanism. The Quarterly Journal of Economics, 84(3), 488. https://doi.org/10.2307/1879431

Altuntas, M., Liebenberg, A. P., Watson, E. D., \& Yildiz, S. (2017). Hedging, Cash Flows, and Firm Value: Evidence of an Indirect Effect. Journal of Insurance Issues, 40(1), 1-22.

Ameer, R. (2010). Determinants Of Corporate Hedging Practices In Malaysia. International Business Research, 3(2), 120-130. https:// doi.org/10.5539/ibr.v3n2p120

Aslikan, I., \& Rokhmi, S. (2017). Faktor-Faktor Yang Mempengaruhi Keputusan Hedging Pada Perusahaan Manufaktur. Jurnal Ilmu Dan Riset Manajemen, 6(5), 1-21.

Brigham, E. F., \& Houston, J. F. (2017). Fundamentals of financial management (p. 631). United States of America: Cengage Learning.

Chaudhry, N. I., Mehmood, M. S., \& Mehmood, A. (2014). Determinants of corporate hedging policies and derivatives usage in risk management practices of non-financial firms. Munich Personal RePEc Archive, (57562), 1-18.

Che, X., Liebenberg, A. P., Liebenberg, I. A., \& Morris, B. C. L. (2018). The effect of growth opportunities on the market reaction to dividend cuts: evidence from the 2008 financial crisis. Review of Quantitative Finance and Accounting, 51(1), 1-17. https://doi.org/ 10.1007/s11156-017-0663-8

Chi, J. D., \& Su, X. (2017). The Dynamics of Performance Volatility and Firm Valuation. Journal of Financial and Quantitative Analysis, 52(1), 111-142. https://doi.org/ 10.1017/S0022109016000788

Combs, J. G., \& Skill, M. S. (2003). Managerialist and Human Capital Explanations for Key Executive Pay Premiums: A Contingency Perspective. Academy of Management Journal, 46(1), 63-73. https://doi.org/10.5465/ 30040676

Costa, J. C. L., \& Singh, J. (2013). Can Hedging Affect Firm Value? An Oil, Gas And Mining Perspective.

Dechow, P. M., \& Dichev, I. D. (2002). Quality Earnings : The The Accruals Accrual Estimation Errors. The Accounting Review, 77(2002), 35-59. 
Dewi, N. K. R. U., \& Purnawati, N. K. (2016). No TitlePengaruh Market to Book Value dan Likuditas Terhadap Keputusan Hedging Pada Perusahaan Manufaktur di BEI. E-Jurnal Manajemen Unud, 5(1), 355 - 384.

Ehrhardt, M. C., Brigham, E. F. (2011). Financial management: theory and practice. United States of America: South-Western Cengage Learning.

Evans, D. S. (1987). The Relationship Between Firm Growth, Size, and Age/ : Estimates for 100 Manufacturing Industries. The Journal of Industrial Economics, 35(4), 567-581. Retrieved from https://econpapers.repec.org/ RePEc:bla:jindec:v:35:y:1987:i:4:p:567-81

Ghozali, I. (2012). Aplikasi Analisis Multivariate dengan Program IBM SPSS 20 (Enam). Semarang: Badan Penerbit Universitas Diponegoro.

Goklas, F., \& Wahyudi, S. (2016). Kebijakan Hedging Dan Faktor-Faktor Yang Mempengaruhinya (Studi Empiris Pada Perusahaan Non Finansial yang Terdaftar Di BEI Periode 2012-2014). Diponegoro Journal of Management, 5(4), 1-14.

Hanifan, A. F. (2017). MNC Sky Vision: Juara yang Selalu Merugi. Retrieved November 30, 2018, from https://tirto.id/mnc-sky-vision-juara-yangselalu-merugi-bliH

Helfert, E. a. (2001). Financial Analysis Tools and Techniques: A Guide for Managers. New York, McGraw-Hill. (McGraw-Hill). New York. https://doi.org/10.1036/0071395415

Hull, J.C. (2018). Options, Futures and Other Derivatives (Ninth Edit, p. 849). Harlow: Pearson Education Limited.

Iyer, S. R., \& Harper, J. T. (2017). Cash flow volatility and investor sentiment. Managerial Finance, 43(2), 178-192. https://doi.org/10.1108/MF-022016-0045

Klimczak, K. M. (2008). Corporate hedging and risk management theory: evidence from Polish listed companies. The Journal of Risk Finance, 9(1), 20-39.https://doi.org/10.1108/152659408 10842393

Koonce, L., Miller, J., \& Winchel, J. (2015). The Effects of Norms on Investor Reactions to Derivative Use. Contemporary Accounting Research, 32(4), 1529-1554. https://doi.org/ 10.1111/1911-3846.12118

Larcker, D., \& Tayan, B. (2011). Corporate Governance Matters A Closer Look at Organizational
Choices and Their Consequences. New Jersey: Pearson Education.

Marcus, Brealey, \& Myers. (2008). Fundamental of Corporate Finance (Sixth). United States of America: McGraw-Hill Primis.

Moguillansky, G. (2003). From Capital Surges to Drought. (R. Ffrench-Davis \& S. GriffithJones, Eds.), From Capital Surges to Drought. London: Palgrave Macmillan UK. https:// doi.org/10.1057/9781403990099

Ng, S., \& Daromes, F. E. (2016). Peran Kemampuan Manajerial Sebagai Mekanisme Peningkatan Kualitas Laba Dan Nilai Perusahaan. Jurnal Akuntansi Dan Keuangan Indonesia, 13(2), 174-193. https://doi.org/10.21002/jaki.2016.10

Nugraha, M. C. (2017). Peran Volatility Cash Flow Dan Kesempatan Bertumbuh Perusahaan Dalam Menekan Financial Distress Dengan Peningkatan Penggunaan Hedging Forward Contract. Universitas Atma Jaya Makassar.

Paminto, A., Setyadi, D., \& Sinaga, J. (2016). The Effect of Capital Structure, Firm Growth and Dividend Policy on Profitability and Firm Value of the Oil Palm Plantation Companies in Indonesia. European Journal of Business and Management, 8(33), 123-134.

Purwanto, D. (2013). Rugi Kurs Laba PLN Anjlok. Retrieved from Kompas: Retrieved December 10, 2018, from https://ekonomi.kompas.com/ $\operatorname{read} / 2013 / 04 / 14 / 0957499 /$ Rugi.Kurs.Laba. PLN.Anjlok

Repie, R. R., \& Sedana, I. B. P. (2015). Kebijakan Hedging Dengan Instrumen Derivatif Dalam Kaitan Dengan Underinvestment Problem Di Indonesia. E-Jurnal Manajemen Unud, 384398.

Scott, W. R. (2015). Financial accounting theory. Prentice Hall Canada (Seventh Ed). Totonto: Pearson.

Spence, M. (1973). Job Market Signaling. The Quarterly Journal of Economics, 87(3), 355. https://doi.org/10.2307/1882010

Tumirin. (2005). Analisis variabel akuntansi kuartalan, variabel pasar, dan arus kas operasi yang mempegaruhi bid-ask spread. Jurnal Akuntansi \& Audit Indonesia, 9(1), 61-75.

Vaughan, E. J., \& Vaughan, T. M. (2014). Fundamentals of Risk and Insurance. The Journal of Risk and Insurance (Elevent Edition). United States of America: Wiley. 